\title{
Protective Effects of Interactional Justice on Job Insecurity of Chinese Workers: Evidence from a large-scale State-owned Telecom Company ${ }^{*}$
}

\author{
Xie Yi Zhong \\ School of Economics \& Management, Nanjing University of Sci. \& Tech. \\ Institute of Psychology, Chinese Academy of Sciences \\ xieyz@psych.ac.cn \\ Wang Xiao $\mathrm{Lu}^{1}$ \\ Centre on Behavioral Health, The University of Hong Kong \\ wangx11219@gmail.com \\ Siu Oi Ling \\ Department of Sociology and Social Policy, Lingnan University, Hong Kong \\ siuol@ln.edu.hk \\ Shi Kan \\ Management School of Graduate University of Chinese Academy of Sciences \\ shik@gucas.ac.cn
}

\begin{abstract}
The study attempted to explore protective effects of procedural justice on job insecurity and job attitudes of Chinese workers in the face of an impending organizational change. In a large-scale state-owned telecom company and its four subsidiary companies in China where a fundamental organizational change was about to take place, 592 employees were randomly sampled and surveyed. The results of hierarchical regression analysis show that procedural justice could bolster employees' job satisfaction and organizational commitment partially through reducing their job insecurity. Further analysis of this partial mediating effect, in terms of two components of procedural justice, revealed a protective effect of interactional justice instead of formal procedure on job insecurity of Chinese employees in the face of the forthcoming organizational change. Implications for measures protecting employees' psychological well-being in the decision-making process of human resource management leading up to organizational change are discussed later.
\end{abstract}

Keywords: job insecurity, procedural justice, interactional justice, job satisfaction, organizational commitment

\section{Introduction}

Most of the workers in Chinese state-owned companies are under permanent contracts due to the previous centrally-planned economy. However, following the trend of social and economic transition in China, more and more state-owned companies have transformed into joint-stock companies with the cost of large-scale layoffs. As a consequence, even among employees with permanent contracts in state-owned enterprises (SOEs), job insecurity has been reported as one of the most important work stressors in the past decade[1]. A plethora of research have been dedicated to psychological well-being of layoff survivors after organizational change, while limited knowledge is available regarding the effects of contextual factors in the decision process of redeployments and layoffs before organizational change on employees' job insecurity and work-related attitudes such as job satisfaction and organizational commitment.

\section{Theoretical Framework and Hypotheses}

Morrison and Robinson[2] recognized that the cognitive assessment of organizational context that surrounds a perceived contract breach involves an interpretation of how fairly the individual bound with the contract is treated by the organization during the breaching process. Early research of organizational

\footnotetext{
* This research was supported by the National Natural Science Foundation of China [grant numbers 90924007, 2010CB731406]

${ }^{1}$ Corresponding author: Wang Xiao Lu, wangx11219@gmail.com

978-1-4244-6359-6/10/\$26.00 @2010 IEEE
} 
justice paid more attention to distributive justice and its impacts. However, more and more researchers have recognized that the procedures which determine a certain result are even more important than the result per se to the emotional, cognitive, and behavioral reactions to the injustice[3, 4]. Greenhalgh and Rosenblatt[5] contended that if an organization lacks imperative institutions to ensure justice or employees have no voice in their job-relevant decision making and no chance to bargain for their interests, feelings of helplessness and grievance will be generated among those workers when they are in the face of threats to their jobs. It in turn will aggravate their job insecurity.

Hypothesis 1: in the face of an impending organizational change, employees with higher perception of procedural justice will have lower job insecurity, while those with lower perception of procedural justice will have higher job insecurity.

Essentially, job insecurity comes from worries about losing one's job or losing some important characteristics of the job such as working conditions, career opportunities[5]. Once it happens, a worker usually will generate negative emotional reaction to the job per se, contributing to a decrease in job satisfaction. Likewise, when employees feel insecure about their future roles in the organization, their attachment to the organization including organizational commitment and trust will be lowered[6, 7].

Hypothesis 2: Job insecurity will lead to a decrease in job satisfaction and organizational commitment of employees before organizational change.

Thibaut and Walker[8] suggested that a prerequisite of individuals engaging in the rules or procedures set forth by the organization is the belief that these rules will promote equitable behavior and assist them in achieving personal gain. Procedures are seen as instruments that ensure individuals to receive fair and positive rewards and benefits (e.g., organizational promises) in the long term through social exchange. Thus, procedural justice has been demonstrated by many studies to be positively associated with employees' job satisfaction and organizational commitment[9, 10]. To replicate the findings among Chinese employees, we again hypothesized that.

Hypothesis 3: Perception of procedural justice before organizational change is positively related to overall job satisfaction and organizational commitment of employees.

Taken together, procedural justice before organizational change and layoffs may exert a great impact on job insecurity and job satisfaction as well as organizational commitment. Job insecurity might also have a significant effect on job satisfaction and organizational commitment. Accordingly, we postulate that job insecurity might act as a mediator between procedural justice and job satisfaction as well as organizational commitment. We therefore hypothesized that

Hypothesis 4: Job insecurity of employees confronted with a forthcoming organizational change mediates the influence of procedural justice on their job satisfaction and organizational commitment.

\section{Method}

\subsection{Participants and procedures}

592 participants were recruited from three functional departments of the headquarter and four subsidiary companies of a large state-owned telecom enterprise in China. During data collection of this study, this company was about to carry out a fundamental transformation from a state-owned company to a joint-stock company. All participants filled in the questionnaires voluntarily and anonymously which were then immediately mailed back to researchers directly. The survey was completed in three days. The demographic information is presented in the Table 1.

Table 1 Demographic information of respondents

\begin{tabular}{|c|c|c|c|}
\hline \multicolumn{2}{|c|}{ Demographic Variables } & \multirow{2}{*}{$\frac{n}{263}$} & \multirow{2}{*}{$\begin{array}{r}\text { Percentage } \\
44.4 \%\end{array}$} \\
\hline Gender & Female & & \\
\hline & Male & 320 & $54.1 \%$ \\
\hline & Unidentified & 9 & $1.5 \%$ \\
\hline Marital & Single & 173 & $29.2 \%$ \\
\hline \multirow{2}{*}{ Status } & Married & 392 & $66.2 \%$ \\
\hline & Unidentified & 27 & $4.6 \%$ \\
\hline \multirow[t]{6}{*}{ Age } & 18-24 years old & 68 & $11.5 \%$ \\
\hline & 25-34 years old & 269 & $45.4 \%$ \\
\hline & $35-44$ years old & 171 & $28.9 \%$ \\
\hline & $45-54$ years old & 75 & $12.7 \%$ \\
\hline & $\begin{array}{l}\text { above } 55 \text { years } \\
\text { old }\end{array}$ & 5 & $0.8 \%$ \\
\hline & Unidentified & 4 & $0.7 \%$ \\
\hline \multirow{9}{*}{$\begin{array}{l}\text { Educational } \\
\text { Level }\end{array}$} & middle school & 10 & $1.7 \%$ \\
\hline & level or below & & \\
\hline & $\begin{array}{l}\text { high school level } \\
\text { (including }\end{array}$ & 122 & $20.6 \%$ \\
\hline & $\begin{array}{l}\text { technical } \\
\text { secondary school) }\end{array}$ & & \\
\hline & $\begin{array}{l}\text { junior college } \\
\text { level }\end{array}$ & 433 & $73.1 \%$ \\
\hline & (including & & \\
\hline & $\begin{array}{l}\text { bachelor degree) } \\
\text { master degree }\end{array}$ & 23 & $3.9 \%$ \\
\hline & level or above & & \\
\hline & Unidentified & 4 & $0.7 \%$ \\
\hline \multirow[t]{3}{*}{ Job Tenure } & $1-4$ years & 102 & $17.2 \%$ \\
\hline & 5 - 9 years & 106 & $17.9 \%$ \\
\hline & $10-14$ years & 129 & $21.8 \%$ \\
\hline
\end{tabular}




\begin{tabular}{llrr} 
& 15-19 years & 96 & $16.2 \%$ \\
& more than 20 & 149 & $25.2 \%$ \\
& years & 10 & $1.7 \%$ \\
\hline Unidentified & 354 & $59.8 \%$ \\
& general workers & 54 & $9.1 \%$ \\
& senior workers & 27 & $4.6 \%$ \\
& Supervisors & 17 & $2.9 \%$ \\
& managers or & & \\
above & 106 & $17.9 \%$ \\
& other positions & 34 & $5.7 \%$ \\
\hline Unidentified & &
\end{tabular}

\subsection{Measures}

Procedural Justice. We adopted the procedural justice instrument originally developed by Moorman. It includes two closely related but independent dimensions: formal procedure and interactional justice $[11,12]$. The two distinctive constructs of procedural justice were confirmed by the current study using confirmatory factor analysis (CFA) using Amos 16.0 statistical packages (Chi-squared $=504.44, \mathrm{df}=76$, NFI $=.98, \quad$ RFI $=.97, \quad$ IFI $=.98, \quad$ TLI $=.98, \quad$ CFI $=.98$, RMSEA $=.10$ ). In this study, the Cronbach's alpha of procedural justice, formal procedure and interactional justice were $0.94,0.88$, and 0.90 respectively.
Job Insecurity. We adopted the job insecurity instrument developed by Caplan et al.[13]. In this study, the Cronbach's alpha of this scale was 0.69 .

Overall Job Satisfaction. Job satisfaction was examined by Agho and Price's overall job satisfaction scale[14]. In this study, the Cronbach's alpha of this scale was 0.89 .

Organizational Commitment. We used the organizational commitment instrument developed by Cook and Wall[15]. In this study, the Cronbach's alpha of this scale was 0.79 .

All of the instruments were translated and back translated from original English versions.

\subsection{Data analysis}

The procedures proposed by Baron and Kenney [16] were adopted to test the mediating role of job insecurity.

\section{Results}

\subsection{Descriptive statistics for study variables}

The descriptive statistics and correlations among demographic variables, independent variables, mediating variables, as well as dependent variables are depicted in Table 2.

Table 2 Descriptive statistics of study variables and their correlation coefficients matrix

\begin{tabular}{|c|c|c|c|c|c|c|c|c|c|c|c|c|}
\hline & \multirow{2}{*}{ Mean } & \multirow{2}{*}{ SD } & \multicolumn{10}{|c|}{ Correlations } \\
\hline & & & 1 & 2 & 3 & 4 & 5 & 6 & 7 & 8 & 9 & 10 \\
\hline 1 Gender $^{b}$ & $\mathrm{NA}^{\mathrm{a}}$ & NA & - & & & & & & & & & \\
\hline $2 \mathrm{Age}^{\mathrm{c}}$ & 2.46 & .89 & $-.10^{*}$ & 一 & & & & & & & & \\
\hline 3 Marital status ${ }^{\mathrm{d}}$ & NA & NA & $.22 * *$ & $.58 * *$ & - & & & & & & & \\
\hline 4 Education $^{\mathrm{e}}$ & 2.80 & .52 & $-.10 *$ & $-.21 * *$ & $.10 *$ & - & & & & & & \\
\hline 5 Job tenure ${ }^{\mathrm{f}}$ & 3.14 & 1.43 & $-.12 * *$ & $.86^{* *}$ & $-.67 * *$ & $-.25 * *$ & - & & & & & \\
\hline $6 \mathrm{Job}$ level ${ }^{\mathrm{g}}$ & 1.35 & .76 & -.06 & $.32 * *$ & $-.31 * *$ & $.17 * *$ & $.31 * *$ & - & & & & \\
\hline 7 Procedural Justice & 44.74 & 10.18 & .03 & -.07 & .07 & -.07 & -.08 & -.09 & - & & & \\
\hline 8 Job Satisfaction & 21.59 & 4.27 & -.01 & $.24 * *$ & $-.19 * *$ & $-.11 * *$ & $.26 * *$ & $.15^{* *}$ & $.31 * *$ & - & & \\
\hline 9 Org. Commitment & 46.12 & 8.59 & -.08 & $.29 * *$ & $-.23 * *$ & $-.14 * *$ & $.35 * *$ & $.14^{*}$ & $.30 * *$ & $.59 * *$ & - & \\
\hline 10 Job Insecurity & 10.77 & 2.73 & $-.14 * *$ & -.02 & .03 & .02 & -.03 & -.01 & $-.25 * *$ & $-.34 * *$ & $-.31 * *$ & 一 \\
\hline
\end{tabular}

${ }^{a}$ NA: Not Applicable.

${ }^{b}$ Gender: 0 = female; 1 = male.

${ }^{c}$ Age: $1=18-24$ years old; $2=25-34$ years old; $3=35-44$ years old $; 4=45-54$ years old; $5=$ above 55 years old.

${ }^{d}$ Marital status: $0=$ married; 1 = single.

${ }^{e}$ Education: 1 = middle school level or below; 2 = high school level (including technical secondary school);

$3=$ junior college level (including bachelor degree); 4 = master level or above.

${ }^{f}$ Job tenure: $1=1-4$ years; $2=5-9$ years; $3=10-14$ years; $4=15-19$ years; $5=$ more than 20 years.

${ }^{g}$ Job level: 1 = general workers; 2 = senior workers; 3 =supervisors; 4 = managers or above.

$* p<.05 ; * * p<.01$

As shown in Table 2, none of the demographic variables was found significantly related to procedural justice. Only gender was significantly related to job insecurity, overall job satisfaction and organizational 
commitment. There were significant correlations between all independent variables, mediating variables, and dependent variables.

\subsection{Results of mediation analysis}

We controlled participants' demographic variables to test mediating effects of job insecurity on the relationships between procedural justice and job satisfaction as well as organizational commitment.

Table 3 Results of regression analysis for mediation with procedural justice as a predictor ${ }^{\text {a }}$

\begin{tabular}{|c|c|c|c|}
\hline \multirow[b]{2}{*}{ Variables } & \multirow{2}{*}{$\begin{array}{c}\text { Model1 } \\
\text { Job } \\
\text { Insecurity }\end{array}$} & \multicolumn{2}{|c|}{ Model2 $^{b}$} \\
\hline & & $\begin{array}{c}\text { Job } \\
\text { Satisfaction } \\
\end{array}$ & $\begin{array}{c}\text { Org. } \\
\text { Commitment } \\
\end{array}$ \\
\hline \multicolumn{4}{|l|}{ Controls } \\
\hline Gender & $-.157 * *$ & .047 & -.030 \\
\hline Age & .016 & .017 & -.076 \\
\hline $\begin{array}{l}\text { Marital } \\
\text { status }\end{array}$ & .021 & -.046 & .008 \\
\hline Education & -.028 & $-.127 *$ & -.063 \\
\hline Job tenure & -.093 & .169 & $.336^{* *}$ \\
\hline Job level & .023 & $.119 *$ & .058 \\
\hline$\Delta \mathrm{R}^{2}$ & .027 & $.104 * *$ & $.099 * *$ \\
\hline \multicolumn{4}{|c|}{ Direct effect } \\
\hline $\begin{array}{l}\text { Procedural } \\
\text { justice }\end{array}$ & $-.287 * *$ & $.305^{* *}$ & $.316^{* *}$ \\
\hline$\Delta \mathrm{R}^{2}$ & $.081 * *$ & $.091 * *$ & $.098 * *$ \\
\hline \multicolumn{4}{|l|}{$\begin{array}{l}\text { Mediating } \\
\text { effects }\end{array}$} \\
\hline $\begin{array}{l}\text { Procedural } \\
\text { justice }\end{array}$ & & $.210 * *$ & $.221 * *$ \\
\hline $\begin{array}{l}\text { Job } \\
\text { insecurity }\end{array}$ & & $-.324 * *$ & $-.308 * *$ \\
\hline$\Delta \mathrm{R}^{2}$ & & $.185 * *$ & $.182 * *$ \\
\hline Overall $\mathrm{R}^{2}$ & & .289 & .280 \\
\hline $\begin{array}{l}\text { Overall } \\
\text { model F }\end{array}$ & & $18.819^{* *}$ & $18.047 * *$ \\
\hline
\end{tabular}

${ }^{a}$ Listwise deletion was adopted. Standardized regression coefficients are shown.

${ }^{b}$ In testing for direct effects (model 2), we entered the controls and procedural justice in two separate steps. In testing for mediation effects (model 2), we entered the controls in the first step, then entered procedural justice and the mediators in the second step. We only report the regression results of controls in the first step.

$* p<.05 ; * * p<.01$

As shown in Table 3, all the four hypotheses were supported. However, the attenuation in the $\beta$ coefficients of regression of procedural justice on job satisfaction and organizational commitment indicated a partial mediating effect of job insecurity.

To understand the partial mediating effect of job insecurity, we further examined the mediating effects of job insecurity on formal procedure and interactional justice respectively, with demographic variables being controlled.

Table 4 Results of regression analysis for mediation with formal procedure and interactional justice as predictors $^{\text {a }}$

\begin{tabular}{lrrr}
\hline \multirow{2}{*}{ Variables } & \multicolumn{1}{c}{ Model1 } & \multicolumn{2}{c}{ Model2 $^{\mathrm{b}}$} \\
\cline { 2 - 4 } & $\begin{array}{c}\text { Job } \\
\text { Insecurity }\end{array}$ & $\begin{array}{c}\text { Job } \\
\text { Satisfaction }\end{array}$ & $\begin{array}{c}\text { Org. } \\
\text { Commitment }\end{array}$ \\
\hline Controls & & & -.030 \\
Gender & $-.157^{* *}$ & .047 & -.076 \\
Age & .016 & .017 & .008 \\
Marital & .021 & -.046 & -.063 \\
status & & & $.336^{* *}$ \\
Education & -.028 & $-.127^{*}$ & .058 \\
Job tenure & -.093 & .169 & $.099 * *$ \\
Job level & .023 & $.119^{*}$ & $.104^{* *}$ \\
$\Delta \mathrm{R}^{2}$ & .027 & &
\end{tabular}

Direct effect

Formal

$-.008$

.169

procedure

Interactional $-.289 * *$

.146

$.293 * *$

justice

$\Delta \mathrm{R} 2$

$.086^{* *}$

$.091 * *$

$.201 * *$

Mediating

effects

Formal

procedure

Interactional

Justice

Job

insecurity

$\Delta \mathrm{R} 2$

Overall R2

Overall

model $\mathrm{F}$

${ }^{a}$ Listwise deletion was adopted. Standardized regression coefficients are shown.

${ }^{b}$ In testing for direct effects (model 2), we entered the controls and formal procedure and interactional justice in two separate steps. In testing for mediation effects (model 2), we entered the controls in the first step, then entered formal procedure and interactional justice and the mediators in the second step. We only report the regression results of controls in the first step.

$* p<.05 ; * * p<.01$ 
As shown in Table 4, formal procedure was not related to workers' job insecurity, overall job satisfaction or organizational commitment. Job insecurity only partially mediated the relationship between interactional justice and organizational commitment.

\section{Discussion}

The current study attempted to investigate the impact of procedural justice on job insecurity of workers in the face of an impending organizational change and layoffs, and resulting work-related attitudes, namely job satisfaction and organizational commitment. The results support all of the hypotheses in the proposed model. Procedural justice could reduce employees' job insecurity, which in turn partially resulted in higher overall job satisfaction and organizational commitment. In addition, formal procedure was not found to be related to workers' job insecurity, overall job satisfaction or organizational commitment. The mediating effect of job insecurity was found only existed between interactional justice and organizational commitment. In other words, the more considerate, respectful, and sincere an employee perceives his/her supervisor in the decision making relevant to his/her job before organizational change, the lower his/her job insecurity will be, thereby contributing to his/her organizational commitment.

These findings revealed an important protective contextual factor in Chinese organizations, interactional justice, to workers' job insecurity and hence their organizational commitment before organizational change. It has enriched our knowledge concerning job insecurity issues of employees confronted with an impending organizational change. The result provides insights on preventive measures for human resources management leading up to organizational change to bolster employees' job security and work-related attitudes. Specifically, it sheds light on the importance of reinforcing justice in the process of interaction and communication between employers and employees with respect to job-relevant decisions in enterprises before organizational change.

There are many practical implications. For instance, a supervisor should avoid personal biases, consider subordinates' viewpoints, show concern for subordinates' rights, provide timely feedback about the decision process, treat subordinates with kindness and consideration, take steps to deal with subordinates in a truthful manner, and the like. As such, job insecurity among workers in the face of a forthcoming organizational change will be assuaged. In addition, workers' organizational commitment could be maintained and even strengthened instead of turnover intention. Further, workers' well-being could also be enhanced from increased job security and organizational support by interactional justice and formal procedures adopted.

\section{References}

[1] J. L. Xie, "Issues related to globalization, culture, and stress in China," presented at the the Academy of Management Annual Meeting, New Orleans, USA, 2004.

[2] E. Morrison and S. Robinson, "When employees feel betrayed: A model of how psychological contract violation develops," Academy of management Review, vol. 22, pp. 226-256, 1997.

[3] S. Aryee and Y. W. Chay, "Workplace justice, citizenship behavior, and turnover intentions in a union context: Examining the mediating role of perceived union support and union instrumentality," Journal of Applied Psychology, vol. 86, pp. 154-160, 2001.

[4] D. Fields, et al., "Distributive and procedural justice as predictors of employee outcomes in Hong Kong," Journal of Organizational Behavior, vol. 21, pp. 547-562, 2000.

[5] L. Greenhalgh and Z. Rosenblatt, "Job Insecurity: Toward Conceptual Clarity," Academy of Management. The Academy of Management Review, vol. 9, pp. 438-448, 1984.

[6] S. J. Ashford, et al., "Content, Causes, And Consequences Of Job Insecurity: A Theoybased Measure and Substantive Test," Academy of Management Journal, vol. 32, pp. 803-829, 1989.

[7] M. Sverke, et al., "No security: A review and meta-analysis of job insecurity and its consequences," Journal of Occupational Health Psychology, vol. 7, pp. 242-264, 2002.

[8] J. Thibaut and L. Walker, Procedural justice: A psychological analysis: Lawrence Erlbaum Associates Hillsdale, NJ, 1975.

[9] D. B. McFarlin and S. Paul D, "Distributive and Procedural Justice as Predictors of Satisfaction with personal and organizational outcomes," Academy of Management Journal, vol. 35, pp. 626-637, 1992.

[10] Y. Cohen-Charash and P. Spector, "The Role of Justice in Organizations: A Meta-Analysis* 1," Organizational behavior and human decision processes, vol. 86, pp. 278-321, 2001. 
[11] R. H. Moorman, "Relationship between organizational justice and organizational citizenship behaviors: Do fairness perceptions influence employee citizenship?," Journal of Applied Psychology, vol. 76, pp. 845-855, 1991.

[12] D. Mansour-Cole and S. Scott, "Hearing it through the grapevine: The influence of source, leader-relations, and legitimacy on survivors' fairness perceptions," Personnel Psychology, vol. 51, pp. 25-54, 1998.

[13] R. D. Caplan, et al., Job demands and worker health. Cincinnati, OH: National Institute for Occupational Safety and Health, 1975.

[14] A. O. Agho, et al., "Discriminant validity of measures of job satisfaction, positive affectivity and negative affectivity," Journal of Occupational and Organizational Psychology, vol. 65, pp. 185-196, 1992.

[15] J. Cook and T. Wall, "New work attitude measure of trust, organizational commitment and personal need non-fulfilment," Journal of Occupational Psychology, vol. 53, pp. 39-52, 1980.

[16] R. M. Baron and D. A. Kenny, "The Moderator-Mediator variable distinction in social psychological research: conceptual, strategic, and statistical considerations," Journal of Personality and Social Psychology, vol. 51, pp. 1173-1182, 1986. 